У, $\triangle \mathrm{K} 378: 316.33$

ББК $74.58+60.560$

DOI 10.22394/1682-2358-2018-6-107-114

N.I. Kuznetsov, post-graduate student of the Saratov Military Order of Zhukov Red Banner Institute of National Guard of the Russian Federation

\section{MILITARY INSTITUTE AS A SELF-LEARNING SOCIAL ORGANIZATION}

The prerequisites for the transformation of a military institute as a military organization are revealed. The limitations of (traditional) professional educational practices are specified. The main features of a military institute as a learning social organization are presented.

Key words and word-combinations: military institute, learning social organization, creative potential, cadets, training.
Н.И. Кузнецов, адъюнкт Саратовского военного ордена Жукова Краснознаменного института войск начиональной гвардии Российской Федерачии (email: nikolai-kuznietsov-1978@mail.ru)

\section{ВОЕННЫЙ ИНСТИТУТ КАК САМООБУЧАЮЩАЯСЯ СОЦИААЬНАЯ ОРГАНИЗАЦИЯ}

Аннотация. Раскрываются предпосылки трансформации военного института как военной организации. Уточняются недостатки (традиционных) профессионально-образовательных практик. Выявляются особенности военного института как обучающейся социальной организации.

Ключевые слова и словосочетания: военный институт, обучающаяся социальная организация, творческий потенциал, курсанты, обучение.

B условиях современной России проводится существенная сощиально-образовательная реформа высших военных учебных заведений: осуществляется интенсификация военного образования - переход от преимущественно экстенсивных к преимущественно интенсивным формам социально-образовательного развития. Военные институты становятся качественно новым фактором не только профессионацьного роста, но и инновационного развития, состоящего в модернизации военных структур общества. Современный военный вуз - это образовательное учрежАение, ориентированное на формамьное об- 
разовательное развитие курсантов. Согласно российскому законодательству, силовым высшим учебным заведениям делегируются широкие полномочия по организации и реализации военно-профессионацьной образовательной деятельности.

Перед военными институтами ставится задача формирования нового качества профессионацьной подготовки офиџерских каАров, что неотделимо от задачи повышения профессионально-образовательного развития российского общества [1]. Это преАполагает, с одной стороны, усиление востребованности полученного комплекса знаний относительно последующей профессиональной деятельности будущих офищеров; с Аругой стороны, развитие творческих способностей обучаемых. Аостижение нового качества профессионально-образовательного развития призвано не только обеспечить рост эффективности военно-профессиональной деятельности молодых офиџеров, но и повысить престижность военной служббы в целом, обеспечить перспективу Аинамичного карьерного роста офицерского корпуса [2, с. 167-171] .

В рамках новых задач должна быть трансформирована вся система служебно-трудовой деятельности военного института [3, с. 197-201], который в новых условиях не должен оставаться образовательной организацией классического типа. В рамках военной организации классического типа курсант рассматривается в качестве пассивного потребителя образовательных услуг [4, с. 19-29]. Априори он определяется как деструктивно настроенный, сопротивцяющийся Аостижению целей соџиально-профессионального развития, не имеющий образовательных потребностей и интереса к саморазвитию [5, с. 84-90]. Военный институт в кцассическом понимании - это военная социально-образовательная организация, имеющая жесткую структуру и регмаментацию деятельности обучаемых и обучающихся. Она ориентирована на обеспечение усвоения определенного набора знаний, умений, профессионацьных навыков, но изначально не направлена на создание возможностей самостоятельного поиска новых знаний, образовательного самосовершенствования, становцение творческих потребностей и способностей.

Военно-профессионацьный потенциал курсантов в рамках жкестко регламентированных классических военных организаций имеет заранее определенные неизменные формы, практики поиска, обработки и накопления профессиональных знаний, реализуемые в ограниченных формах [6, с. 85-90]. Классическая модель военной социально-образовательной организации в России функционирует Алительное время. Ее сохранение Аолгое время связывамось с рядом факторов: 1) отсутствием самостоятельности и возможности осуществлять комплексную саморегумяцию процессов образования военными вузами; 2) существенной ограниченностью кадровых и материальных ресурсов военных институтов; 3) относительной оторванностью образовательных процессов от системы войсковых частей, непосредственной профессионацьной Аеятельности офицеров после окончания военного института.

Основная особенность классической военной образовательной организации связана с жесткой регламентацией образовательных проџессов, формированием шаблонов необходимых образовательных технологий, мимитировано вы- 
строенными отношениями преподавателей и обучаемых. В данной социальной системе условия образовательной трудовой деятельности не определяются в качестве фактора цемевого развития профессионального потенциала курсантов. Условия образовательной трудовой Аеятельности рассматриваются как набор узких характеристик образовательного процесса, а также внутренней социально-образовательной среды, пассивно воздействующей на курсантов и обеспечивающей возможность регламентировать образовательные процессы. Необходимость активного саморазвития интемеекуального потенщиала курсантов в классической организационной системе не воспринималась в целом как важнейший результат функционирования образовательного учреждения [7, с. 68-78], а потому и не предоставмялись возможности дмя формирования чувства собственной значимости, самоуважения, проектно-управленческой, творческой активности, не обеспечивались условия дмя удовметворения творческих потребностей.

Принятие Федерального закона «Об образовании в Российской Федерации», а также крупномасштабная военная реформа изменили условия, возможности и цели функционирования военного института: ему предоставлена существенная самостоятельность, усилился организационный потенщиал военных институтов, их деятельность интегрирована с системой профессиональной деятельности акторов непосредственных войсковых частей.

Формирование творческого потенциала, основанное на удовлетворении интемлектуальных потребностей, стало важным направлением образовательной Аеятельности в военном институте в качестве самообучающейся соџиальной организации. Творческое развитие и саморазвитие учащихся связано с формированием современного типа профессионального развития, опредемяющим цемевую ориентацию не на жесткую регламентацию дисциплины и порядка, темпы, количественные объемы усвоенных знаний, умений, навыков, а на существенные структурные трансформации в организации образовательных учреждений.

Наиболее важным явмяется привлечение научных, технических, управленческих, образовательно-творческих нововведений, позволяющих, с одной стороны, повысить эффективность образовательного процесса, а с Аругой - моАернизировать качество образования, внеАрить научно-креативные технологии [8, с. 247-253]. Формирование и внедрение эффективных методов развития военного образования способствует обеспечению подготовки высококвацифицированных каАров по всем основным направлениям общественно полезной военно-профессиональной деятельности [9].

Военный институт как самообучающаяся соџиальная организация призван не только создать условия раскрепощения, обработки новых знаний обучаемыми, но и обеспечить стимулирование и поддержку их творческой проектно-трудовой деятельности, связанной с формированием образовательно-трудовых отношений партнерского типа между обучаемыми и преподавателями. В рамках современного военного института необходимо воспитывать толерантность к различным видам служебной деятельности при относительном консерватизме и зависимости «образовательного раз- 
вития от используемых технологий и материальных факторов организации» $[10$, c. 229$]$.

Таким образом, в новых условиях трансформируются принципы функщионирования высших военных образовательных организаций. Сегодня военный институт преАставляет собой самообучающуюся соџиальную систему. В нем проявляются слеАующие особенности самообучения:

1. Формирование динамичных образовательных механизмов военно-профессионального развития, тесно связанного с задачами саморазвития курсантов. Образовательная деятельность рассматривается как процесс научного, интемлектуально-образовательного поиска новых знаний, систематизации информационных потоков, идей, самообучения, основывающегося на принџипах постоянства, системности, цикАичности. Применение системного подхода, с одной стороны, Аолжно обеспечить опережающий характер военно-профессионального образования, с Аругой - создать возможность Аинамичной профессионально-трудовой адаптации, обеспечить готовность к Аеятельности в условиях изменений внешней и внутренней соџиальной среАы военной организации.

В новых условиях военный институт представцяет собой подсистемную структуру инноваџионного компиекса общества. Это изменяющаяся и саморазвивающаяся система за счет внедрения целевых научно-образовательных комплексов, самообучения преподавателей, профессионального роста культурного капитала Аругих сотрудников, внеАряющая общую соџиокультурную стратегию целевого развития военной организационной культуры. Ее структура вкцючает систему обязательной целевой воспитательной деятельности и образовательной профессиональной переподготовки; обновление аАминистративного нормативного регулирования поведенческих практик курсантов; расширение возможностей и необходимости внеАрения внешних инновационных технологий и новых научных разработок.

В современных условиях одной из основных характеристик военного института как самообучающейся соџиальной организаџии является его спеџифическая военная организаџионная культура: система военных инновационных ценностей, моделей научно-образовательного взаимодействия, различных систем норм формального поведения, вкцючая военное и образовательное, набор стандартов поведения. Формируется новая военная организационная культура, направленная на достижение конечных результатов культурно-образовательного роста, накопления как традиционного, так и нового профессионального потенциала курсантов.

2. Трансформация организационных условий жкизнедеятельности курсантов, конструирование творческого профессионального потенциала. Создание условий, при которых возможно и необходимо совершенствовать творческие потребности в научно-образовательной деятельности, научном проектировании, участии в практиках тактического самоуправления неотделимо от разработки и внеАрения процессов конструирования широкой модели профессионального потенџиала будущего офицера. Военный институт призван смоделировать систему необходимых новаторских профессиональных качеств 
курсантов, нацеменную на эффективное обеспечение условий построения их военной карьеры.

В настоящее время происходят существенные изменения в системе организационных отношений военного института:

во-первых, демократизируются отношения курсантов и преподавателей, передается часть образовательных управленческих функций акторам обучения, формируются принщипы самоуправления в комплексе взаимодействия препоАавателя и курсанта;

во-вторых, скцадываются ценности относительной свободы творчества как субъекта, так и объекта образовательной деятельности. В данном контексте субъект, а также объект образовательной деятельности нередко меняются местами, формируют кооперативный образ решения общих образовательных задач, достижения поставленных цемей;

в-третьих, развитие научных практик, проџессов самообучения осуществляется на основе активизаџии как прямых, так и обратных взаимодействий преподавателя и курсанта. Повышается значимость создания возможностей и стимулирования обратных образовательных социальных связей, что призвано обеспечивать необходимость процессов формирования новаторских самоуправленческих команд преподавателей и курсантов, действие которых направлено на подвижные военно-профессиональные специализации.

3. Становление центров формального научного творчества курсантов. Аанные центры разрабатывают проекты и осуществляют непосредственную организацию формальной научной деятельности, обеспечивают нацеленность курсантов не только на постоянный поиск, обработку, систематизацию, но также на создание и внедрение новых военно-профессиональных знаний. Все больший состав образовательных и научных процессов связан с поиском, систематизацией, усвоением знаний, а также адаптацией рационально-правового знания дяя посмедующего военно-профессионального использования, реализации практик самообучения.

4. Модернизация системы управления образовательными процессами военного института. Этот проџесс связан с максимально возможной деџентрализации и демократизацией отношений обучающего и обучаемого. Формирование деятельности, направленной на достижение поставленной цели, способствует привлечению курсантов к организации образовательной и самообразовательной деятельности, внеАрению социальных проектов модернизации образовательной деятельности, целевому развитию не только способностей, но и потребностей к творческой образовательной, научной, проектно-инновационной и самоуправленческой деятельности.

5. ВнеАрение системы стимулирования научно-образовательного труда. Аостижение поставленной цели обусловливает формирование специфической системы стимулирования научно-образовательных практик служебнотрудовой деятельности курсанта, научного обновмения их военного профессионализма, готовности к поиску новой (необходимой) информации, самообучению как во время учебы, так и в процессе реализации военной 
службы. Наиболее существенные компоненты новой стимулирующей системы определяются материальными и нематериальными факторами. Материальные факторы стимулирования основываются на технологиях экономических санкций (Аишение надбавок к стипендии) и поошрений (формирование надбавок, премий, поощрений). В новых условиях они подкрепляются размичными технологиями административного стимулирования: формированием новых правил и процедур научной самостоятельной работы, норм, инновационных ценностей, комплекса административных проверок. Нематериальные факторы стимулирования включают в себя проекты совершенствования условий служебно-образовательной деятельности, быта, соџиокультурного развития курсантов. Аанное проектное конструирование приводит к обновлению потребностей обучаемых, развитию мотивов образовательной деятельности, побуждений к неформальной трудовой научной деятельности в целях достижения собственных, комлективных, а также организационных результатов.

Военный институт как самообучающаяся социальная организация предпомагает рассмотрение нематериальных факторов стимулирования образовательной деятельности в качестве приоритетного комплекса инноваџионной мотивации. В новых условиях материальные стимулирующие факторы отходят на второй план. При этом именно материальные факторы фиксируют не только условия роста материального довольствия курсантов, но и обеспечивают экономические возможности саморазвития их интемеекта, в частности, возможность покупки компьютера, программного обеспечения, коммуникационной техники, доступа к интернет-ресурсам.

Нематериальные факторы стимулирования реализуются преимущественно через следующие соџиальные технологии: мотиваџия достижения научно-образовательных целей; признание мичностных устремлений курсанта; стимумирование через условия образовательной и научной деятельности, создание специальных условий Аля удовлетворения научно-образовательных потребностей, обеспечение возможностей научной деятельности в процессе организации досуга, обеспечение карьерного роста (получение очередного звания, назначение на должность).

Становление факторов достижения опредемяет приоритеты развития российского военного образования: обеспечение организаџионных возможностей непосредственного участия в решении поставленных задач; достижение общей образовательной цели как на уровне деятельности отАельного отАеления, так и взвода, роты, военного института. По сути, самообучающийся военный институт должен создавать условия, при которых курсанты задействованы во всех циклах научно-образовательной подготовки. Признание научных и образовательных заслуг позволяет курсанту ощутить Аостоинство, значимость военной профессии и самоуважение. В рамках обучающегося военного института особенное значение имеет деятельность руководства и непосредственных преподавателей, направленная на стимулирующее моральное поощрение, предоставление курсантам «стимулирующих отзывов», административной и общественной оценки коммективных и индивидуальных образовательных процессов. 
В данном контексте стимулирование представляет социальную технологию планирования, а также внеАрения различных мероприятий, мотивирующих научную и образовательную деятельность курсантов и преподавателей. Научно-образовательное стимулирование - это прежде всего форма Аолговременного социального воздействия на субъекты и объекты образовательного процесса Амя изменения внутренних мотивированных предпочтений акторов, трансформаџии структуры ценностей, практических норм, а также образовательных интересов как курсантов, так и преподавателей. Стимулирование направлено на формирование инновационных ценностей курсанта, развитие мотивационных основ их научно-образовательного потенциала. Этот потенциал в перспективе домжен превращаться в профессиональный капитал и не только способствовать повышению эффективности военно-профессиональной деятельности будущего офиџера, но и приносить ему дополнительный дохоА, обеспечивать динамичный карьерный рост. Можно констатировать, что стимулирование в условиях формирования самообучающегося военного института ориентировано в первую очередь на создание научно-образовательных ценностей, научно-профессиональных интересов позитивного отношения курсанта и преподавателя к внутренней, а также внешней инновационной среде военной организации. 3Аесь стимулирование - это базовый раздражитель научно-образовательных мотивов курсанта. Оно ориентировано на трансформацию фактических ценнностей, норм, принципов в систему научно приоритетной образовательной культуры акторов.

Таким образом, в современных условиях военный институт трансформирует принципы своего функционирования. Осушествцяется переход от военного института как классической соџиальной организаџии, где курсант рассматривается как деструктивно настроенный, сопротивляющийся достижению целей субъект, к самообучающейся соџиальной организаџии, где курсант представмяет собой активный субъект и объект научно-образовательного развития, саморазвития, самоуправмения.

Создается новая обучающаяся военная организация как сложная образовательная система, характеризуюшаяся не только механизмами научно-образовательного развития, но и специфическими условиями служебнотрудового взаимодействия преподавателей и курсантов. Изменяется вся система отношений военного института. Осуществляется переход от процессов механической передачи учебных курсов преподавателем курсантам к их совместной деятельности, направленной на поиск и обработку знаний, овладение новым набором умений, трансформации военно-профессиональных навыков.

В рамках самообучающегося военного института условия служебно-трудовой образовательной деятельности курсантов рассматриваются как один из факторов образовательного саморазвития. Условия служебно-трудовой деятельности курсантов характеризуются демократизацией образовательного процесса и служебно-трудовой среды в целом, что должно не только сформировать условия саморазвития, но и активно воздействовать на курсантов, создавая возможности поиска и обработки новых знаний, их интемлектуаль- 
ного саморазвития, научно-творческой реализации. По сути, в современном военном институте конструируются принципы самообучения как на уровне преподавательского, так и курсантского состава.

Активизация методов саморазвития военного образования ориентирована на обеспечение самокомпетентностного образовательного подхода в системе профессиональной подготовки офицеров. Происходит отказ от кАассической (традиционной) образовательной подготовки (ориентация на поддержкание железной Аисциплины; регламентация традиционного усвоения стандартной системы военно-профессиональных знаний, умений, навыков) и формирование инновационной самообучающейся образовательной подготовки (ориентация на развитие интемлектуально-творческих способностей; формирование умений работы с информационной средой; навыков прогнозировать и моделировать преАставления о развитии ситуации, понимания последствий собственных профессиональных действий, соџиальной ответственности за ее результаты).

Инноваџионный самообучающийся военный институт способен достичь необходимых конечных образовательных резуиьтатов, так как ориентирован на требования военной практики, заложенные в образовательные программы, и вкцючает общественно необходимые компетенции.

\section{Библиографический список}

1. Путин В.В. Выступление на совещании по вопросам развития системы военного образования. URL: https:/topwar.ru/36139-soveschanie-po-voprosam-razvitiya-sistemy-voennogoobrazovaniya.html

2. Баландина T.M., Хвостанщев С.В. Профессиональная адаптация офицеров национальной гвардии России // Вестник Саратовского государственного социально-экономического университета. 2017. № 3. С. 167-171.

3. Баландина T.M., Немоляев В.В. Социальное конструирование профессиональной культуры работников организации // Вестник Саратовского государственного социально-экономического университета. 2015. № 5 (59). С. 197-201.

4. Карлова Е.Н., Романова Г.А. Подготовка кадров для Вооруженных сил в гражданских вузах: возможности и ограничения // Социология образования. 2015. № 5. С. 19-29.

5. Быченко Ю.Г. Развитие человеческого капитала - важнейшая цель образовательного института // Направления и перспективы развития образования в военных институтах внутренних войск МВД России: сборник научных статей V международной научно-практической конференции: в 2 ч. / под общ. ред. С.А. Куценко. Новосибирск, 2016.

6. Ершов Д.О. Социально трудовое развитие курсантов военного института // Вестник Поволжской академии государственной службы. 2015. № 1 (46). С. 85-90.

7. Карлова Е.Н. Трансформация военного профессионализма в современном обществе // Обозреватель - Observer: научно-аналитический журнал. 2015. № 9. С. 68-78.

8. Быченко Ю.Г., Ершов В.В. Проектное развитие культурного человеческого капитала военнослужащих-контрактников // Известия Саратовского университета. Новая серия. Сер.: Социология. Политология. 2017. Т. 17, № 3. С. 247-253.

9. Об образовании в Российской Федерации: Федер. закон от 29 дек. 2012 г. № 273-Ф3. URL: http://www.consultant.ru/document/cons_doc_LAW_140174/

10. Митюкова E.B. Социальное проектирование обучающейся организации // Российское общество в контексте реализации приоритетных национальных проектов. Саратов, 2007. 